\title{
Systematic Review of Mental Health Problems and Violent Extremism
}

Paul Gill ${ }^{1}$, Caitlin Clemmow ${ }^{1}$, Florian Hetzel $^{1}$, Bettina Rottweiler ${ }^{1}$, Nadine Salman ${ }^{1}$, Isabelle Van Der Vegt ${ }^{1}$, Zoe Marchment ${ }^{1}$, Sandy Schumann ${ }^{1}$, Sanaz Zolghadriha ${ }^{1}$, Norah Schulten ${ }^{2}$, Helen Taylor ${ }^{3}$, Emily Corner ${ }^{3}$

1. Department of Security and Crime Science, UCL

2. Department of Psychology, University of Amsterdam

3. Centre for Social Research \& Methods, Australia National University

\section{Abstract}

A wide range of studies investigating the nature and determinants of radicalisation, and terrorist-related behaviour exist. These, in turn, have influenced theory, policy and practice in areas concerned with violent extremism prevention, disruption and management. As such interventions become more common, debates rage within mental health professions about the role mental health practitioners should play in countering violent extremism. This systematic review assesses the impact of mental health problems upon attitudes, intentions and behaviours in the context of radicalisation and terrorism. We identified 25 studies that measured rates of mental health problems across 28 samples. The prevalence rates are heterogenous and range from $0 \%$ to $57 \%$. If we pool the results of those samples $(n=19)$ purely focused upon confirmed diagnoses where sample sizes are known ( $\mathrm{n}=1705$ subjects), the results suggest a rate of $14.4 \%$ with a confirmed diagnosis. Where studies relied upon wholly, or in some form, upon privileged access to police or judicial data, diagnoses occurred $16.96 \%$ of the time ( $n=283$ subjects). Where studies were purely focused upon open sources ( $\mathrm{n}=1089$ subjects), diagnoses were present $9.82 \%$ of the time. We then explore (a) the types and rates of mental health disorders identified (b) comparison/control group studies (c) studies that explore causal roles of mental health problems and (d) other complex needs. 


\section{Introduction}

A wide range of studies investigating the nature and determinants of radicalisation and terrorist-related behaviour exist. These, in turn, have influenced theory, policy and practice in areas concerned with violent extremism prevention, disruption, and management. This has been particularly true in very recent times in the area of mental health. Examples include the establishment of a joint agency response to the threat of lone-actor grievance-fuelled violence in Australia (Pathé et al., 2018), community engagement approaches in the U.S. (Ellis \& Abdi, 2017), the adoption of gatekeepers at regional prevention units in Germany (Ostwaldt, 2018), mental-health based interventions in Los Angeles and the United Kingdom (Weine et al., 2017; Hurlow et al., 2016; Augestad Knudsen, 2020), and family-based counselling interventions in Germany (Koehler, 2015).

As such interventions become more common, debates rage within mental health professions about the role mental health practitioners should play in countering violent extremism (Summerfield, 2016; McGarry, 2016; James \& Hurlow, 2016; Khoshnood, 2017; Bhui \& Jones, 2017; Dom et al., 2018; Weine \& Kansal, 2019; Younis \& Jadhav, 2019; Augestad Knudsen, 2020). These debates regularly point toward the ambiguities and seemingly contrasting findings uncovered within various empirical studies. However, differences may be a by-product of misunderstandings, methodological approaches, sampling and interpretation. This incentivizes a need for a rigorous synthesis of the existing evidence base. Narrative literature reviews on this topic are plentiful (Victoroff, 2005; Horgan, 2005; Silke, 2004; Gill $\&$ Corner, 2017). However, narrative literature reviews can be susceptible to bias and miss relevant studies due to their non-systematic approach by which literature is sourced. Systematic reviews, on the other hand, collate all empirical evidence that meets pre-specified eligibility criteria.

One systematic review already exists on the relationship between mental health and violent extremism (Misiak et al., 2019). The review presented here differs in a number of ways. We (a) consult different and a greater range of academic databases, (b) use a more extensive search string allowing for studies measuring complex needs (c) do not include studies on personality or personality disorders as this is covered elsewhere in this special issue (see XXXX) (d) conduct forward and backward citation searches (e) include non-English language sources and (f) synthesise different research themes. In its totality, our systematic review assesses the associations, correlates and impacts of mental health problems upon attitudes, intentions and behaviours in the context of radicalisation and terrorism. The following section details the methods used in this review. It describes the inclusion criteria, strategy for identifying studies, search terms, data extraction and management processes, and the configurative synthesis process. Next we outline the results. We report and aggregate prevalence rates of mental health problems, the types and rates of mental health disorders, outlines the use of comparison and control groups, examines the relevance of mental health problems upon the radicalisation process and also reports the rates of a number of other associated complex needs.

\section{Method}

\section{Identifying studies: databases and information sources}

The search strategy for the systematic review was based on the Campbell Collaboration method. Studies were identified using the following search methods: 
1) A keyword search of relevant electronic databases, including grey literature and dissertation databases (see below)

2) Forward and backward citation searches of candidate studies

We initially searched three electronic databases (ProQuest Central Criminology Collection, PsychINFO, Pro Quest Central Social Science Database) in February 2018, and a further three (Scopus, IBSS, Sociological Abstracts) in July 2018.

Full text versions of identified studies were obtained through one of the following means (in order of preference): electronic copies via the university's e-journals service, electronic copies of studies available from elsewhere on the internet, paper copies, electronic/paper copies requested through the inter-library loan system (which sources most materials from the British Library) and electronic/paper copies requested from the authors themselves. When any of the full text versions contain insufficient information to determine their eligibility for inclusion according to our coding strategy (described below), where possible the corresponding author was contacted in an attempt to retrieve this information.

More generally, the review considered published and unpublished (grey) studies. No date restrictions were applied. Studies however had to be available in English, French or German since available resources limited our ability to search and translate studies in other languages.

\section{Search terms}

In order to discover relevant items for the systematic review, a number of search terms were used in the above search engines and electronic databases (see Table 1). These include terms relevant to radicalisation and causation. The latter set of terms were adapted from Bouhana and Wikstrom's (2011) rapid evidence assessment of al-Qaeda influenced terrorism.

Table 1: Search Terms Utilised

\begin{tabular}{|l|l|}
\hline Radicalisation & Causation \\
\hline Terrorist & Factor \\
\hline Insurgent & Mechanism \\
\hline Rebel & Cause \\
\hline Radicalisation & Motive \\
\hline Radicalization & Motivation \\
\hline Radical & Determinant \\
\hline Extremist & Propensity \\
\hline Militant & Trigger \\
\hline & Antecedent \\
\hline & Pathway \\
\hline & Process \\
\hline & Profile \\
\hline & Indicator \\
\hline & Predictor \\
\hline & Susceptibility \\
\hline & Root \\
\hline & Causal \\
\hline & Explanation \\
\hline & Risk \\
\hline
\end{tabular}




\begin{tabular}{|l|l|}
\hline & Vulnerability \\
\hline & Context \\
\hline & Stressor \\
\hline & Behaviour \\
\hline & Behavior \\
\hline & Influence \\
\hline & Personality \\
\hline & Opportunity \\
\hline & Reward \\
\hline & Attitude \\
\hline
\end{tabular}

\section{Criteria for Considering Studies for this Review \& Data Extraction}

The sifting of studies was done in multiple stages.

The first stage of screening involved the review team examining the title and abstract of those studies returned from our electronic and bibliographic searches. All references were first uploaded to the EPPI 4 reviewer software, a web-based program developed by the Social Science Research Unit at the Institute of Education, UCL, to manage and analyse data generated from systematic reviews. ${ }^{1}$ In the first stage, we sought paper titles and abstracts which met the following criteria:

a) The study must have reported an explicit goal of understanding the determinants of radicalisation or behaviour associated with a terrorist offence.

b) Report at least one measure in a quantitative or qualitative sense. Outcome data can comprise official measures (such as police recorded data) or unofficial measures (such as self-reported experiences). These measures could relate to causal mechanisms activated in the context of radicalisation, substantive information relating to the environmental conditions that impact upon radicalisation, or substantive information relating to the offender that impact upon radicalisation.

Studies failing to meet inclusion criteria were excluded (with rates of attrition noted - see Figure 1 below). Excluded studies were flagged as inappropriate in one of several ways. First, many studies were not related to radicalisation, terrorism or political violence. Second, many studies were not empirical. Third, several studies were not focused upon the individual but rather focused upon group-level dynamics. Fourth, book reviews and other similar documents were omitted.

At stage two, full texts were consulted using the same inclusion/exclusion criteria as above. Each of the studies included in stage three were then subjected to backwards and forwards citation searches to pursue further candidate studies. This involved reviewing the titles of each study cited within the initially included study and also the subsequent citations that each candidate study accrued up to and including the end of July 2018. Additional backwards and forwards searches were conducted until all leads were fully checked. Stage four then involved coding the independent variables used in each included study. Those studies that included elements related to mental health and complex needs were brought forward and therefore are included in this systematic review.

\footnotetext{
${ }^{1}$ See: $\underline{\text { http://eppi.ioe.ac.uk/cms/Default.aspx?alias=eppi.ioe.ac.uk/cms/er4 }}$
} 
In late November 2019, we conducted a final forwards citation search for all stage three studies in order to include any relevant mental health and radicalisation/terrorism research that had been published in the intervening 16 months. This search was conducted on Google Scholar.

All items and variables measured in these studies were then coded and synthesised. In the next section, we outline the results.

Unfortunately, the descriptive nature of the papers reviewed typically does not allow for the computation of a reliable effect size (such as in experimental or quasi-experimental evaluation designs with a control group or a suitable single study interrupted time series designs). This makes meta-analyses impossible to conduct. Instead, we report an aggregation of descriptive studies.

The aim of the configurative review is to similarly increase the generalizability of the findings within individual studies and thereby provide theoretical and practical insights that single studies are incapable of doing. We report descriptive statistical findings regularly. Sub-set comparison results are only reported when statistically significant. Given that many studies involve small samples, and are therefore likely underpowered, such results are rare.

\section{Figure 1 Screening Flow Chart [INSERT HERE]}

\section{Results}

We clustered the empirical results into fiive broad themes. The first theme demonstrates the prevalence rates of mental health problems identified across multiple studies on those that have been engaged in violent extremism. The second looks at specific disorders. The third examines the use of control and comparison groups. The fourth looks at the functional role of mental health problems in the development of violent extremism. The fifth theme moves away from mental health disorders and focuses upon complex needs.

\section{Theme 1: Rates of Mental Health Problems}

After omitting duplicate datasets used in multiple studies, we identified 25 studies that measured rates of mental health problems across 28 violent extremist samples. The overwhelming majority of these studies occurred since 2013. The recent increase is partially to do with the increased empiricism within terrorism studies more generally (Schuurman, 2018), but is also the result of a real lack of empirical psychological enquiry until recently (see Gill \& Corner, 2017, for a review).

Table 2 presents these studies chronologically. The prevalence rates are heterogenous and range from $0 \%$ to $57 \%$ (see Figure 1). This is perhaps because the studies differ in numerous ways. First, they measure different constructs of mental health problems. 19 studies reported confirmed diagnosed mental disorders. 7 studies reported mental health problems typically noted as any adverse psychological process experienced. The latter presumably has less stringent inclusion than a formal diagnosis.

Second, the studies use different data collection techniques. Of those studies looking at confirmed diagnoses, four measured these directly via clinical interviews or other associated measures, and one did so via non-clinical self-report. Other studies measured mental health 
concerns indirectly through an investigation of either closed source $(n=4)$ or open source information $(n=10)$. Of those studies with less stringent definitions, one applied self-report measures, three relied upon police files and three depended purely upon openly available statements from those close to the subject.

Third, study sample size varied greatly. If we pool the results of those samples $(n=19)$ purely focused upon confirmed diagnoses where sample sizes are known ( $\mathrm{n}=1705$ subjects), the results suggest a rate of $14.4 \%$ with a confirmed diagnosis. However, this is likely slightly inflated as multiple studies focus on similar populations of terrorists (e.g. lone actors) or geographical remits (e.g. U.S.).

There is a clear difference in the prevalence of confirmed diagnosis dependent upon data source. Where clinical examinations occur ( $\mathrm{n}=236$ subjects), diagnoses were present $33.47 \%$ of the time. Where studies relied upon wholly, or in some form, upon privileged access to police or judicial data, actual diagnoses occurred $16.96 \%$ of the time ( $\mathrm{n}=283$ subjects). Studies based on open sources ( $n=1089$ subjects), reported diagnoses $9.82 \%$ of the time. Not all studies based on open sources are created equally, so great care should be taken to understand their provenance, the depth of sources encountered, and the level of resourcing put into the coding process (see Gill, 2020 for a greater discussion).

Table 2: Attributes of Violent Extremism Studies Reporting Mental Health Problems Prevalence Rates

\begin{tabular}{|c|c|c|c|c|c|}
\hline Study & Sample & Measured & Data & $\mathrm{N}$ & Prevalence \\
\hline $\begin{array}{l}\text { Lyons \& Harbinson } \\
\text { (1986) }\end{array}$ & $\begin{array}{l}\text { Ethno-National } \\
\text { (Northern } \\
\text { Ireland) }\end{array}$ & $\begin{array}{l}\text { Confirmed } \\
\text { Diagnosis }\end{array}$ & $\begin{array}{l}\text { Clinical } \\
\text { Examination }\end{array}$ & 47 & $17.0 \%$ \\
\hline $\begin{array}{l}\text { Hewitt (2003) Sub- } \\
\text { Sample A }\end{array}$ & $\begin{array}{l}\text { U.S. Group } \\
\text { Terrorists }\end{array}$ & $\begin{array}{l}\text { Confirmed } \\
\text { Diagnosis }\end{array}$ & Open Source & $?^{2}$ & $8.1 \%$ \\
\hline $\begin{array}{l}\text { Hewitt (2003) Sub- } \\
\text { Sample B }\end{array}$ & $\begin{array}{l}\text { U.S. Lone-Actor } \\
\text { Terrorists }\end{array}$ & $\begin{array}{l}\text { Confirmed } \\
\text { Diagnosis }\end{array}$ & Open Source & $?$ & $22.0 \%$ \\
\hline Bakker (2006) & $\begin{array}{l}\text { European } \\
\text { Jihadists }\end{array}$ & $\begin{array}{l}\text { Confirmed } \\
\text { Diagnosis }\end{array}$ & Open Source & 242 & $4.54 \%$ \\
\hline $\begin{array}{l}\text { Gruenewald et al. } \\
\text { (2013) Sub-Sample } \\
\text { A }\end{array}$ & $\begin{array}{lr}\text { U.S. } & \text { Far-Right } \\
\text { Group Terrorists }\end{array}$ & $\begin{array}{l}\text { Confirmed } \\
\text { Diagnosis }\end{array}$ & Open Sources & 92 & $7.6 \%$ \\
\hline $\begin{array}{l}\text { Gruenewald et al. } \\
\text { (2013) Sub-Sample } \\
\text { B }\end{array}$ & $\begin{array}{l}\text { U.S. Far-Right } \\
\text { Lone-Actor } \\
\text { Terrorists }\end{array}$ & $\begin{array}{l}\text { Confirmed } \\
\text { Diagnosis }\end{array}$ & Open Sources & 47 & $40.4 \%$ \\
\hline Leygraf (2014) & $\begin{array}{l}\text { German } \\
\text { Jihadists }\end{array}$ & $\begin{array}{l}\text { Confirmed } \\
\text { Diagnosis }\end{array}$ & $\begin{array}{l}\text { Clinical } \\
\text { Examination }\end{array}$ & 29 & $17.2 \%$ \\
\hline Gill et al. (2014) & $\begin{array}{l}\text { Lone-Actor } \\
\text { Terrorists }\end{array}$ & $\begin{array}{l}\text { Confirmed } \\
\text { Diagnosis }\end{array}$ & Open Source & 119 & $31.9 \%$ \\
\hline $\begin{array}{l}\text { Corner and Gill } \\
(2015)\end{array}$ & Group Terrorists & $\begin{array}{l}\text { Confirmed } \\
\text { Diagnosis }\end{array}$ & Open Source & 119 & $3.4 \%$ \\
\hline Capellan (2015) & U.S. Lone Wolf & $\begin{array}{l}\text { Confirmed } \\
\text { Diagnosis }\end{array}$ & Open Source & 40 & $25.6 \%$ \\
\hline
\end{tabular}

\footnotetext{
${ }^{2}$ The lead author has sought clarification with Hewitt on this issue.
} 


\begin{tabular}{|c|c|c|c|c|c|}
\hline $\begin{array}{l}\text { Chermak \& } \\
\text { Gruenewald (2015) } \\
\text { Sub-Sample A }\end{array}$ & U.S. Far-Left & $\begin{array}{l}\text { Confirmed } \\
\text { Diagnosis }\end{array}$ & Open Source & 182 & $0.6 \%$ \\
\hline $\begin{array}{l}\text { Chermak \& } \\
\text { Gruenewald (2015) } \\
\text { Sub-Sample B }\end{array}$ & U.S. Jihadists & $\begin{array}{l}\text { Confirmed } \\
\text { Diagnosis }\end{array}$ & Open Source & 155 & $8.3 \%$ \\
\hline Weenink (2015) & Dutch Jihadists & $\begin{array}{l}\text { Confirmed } \\
\text { Diagnosis }\end{array}$ & Police Files & 140 & $6.0 \%$ \\
\hline Perry et al. (2017) & $\begin{array}{l}\text { Palestinian } \\
\text { Vehicle } \\
\text { Attackers }\end{array}$ & $\begin{array}{l}\text { Indications of } \\
\text { Mental } \\
\text { Illness }\end{array}$ & $\begin{array}{l}\text { Closed \& } \\
\text { Open Source }\end{array}$ & 62 & $12.9 \%$ \\
\hline $\begin{array}{l}\text { Van Leyenhorst \& } \\
\text { Andreas (2017) }\end{array}$ & Dutch Jihadists & $\begin{array}{l}\text { Confirmed } \\
\text { Diagnosis }\end{array}$ & Judicial Data & 26 & $15.4 \%$ \\
\hline $\begin{array}{l}\text { Capellan \& Anisin } \\
\text { (2018) }\end{array}$ & U.S. Lone Wolf & $\begin{array}{l}\text { Indications of } \\
\text { Mental } \\
\text { Illness }\end{array}$ & Open Source & 45 & $43.6 \%$ \\
\hline King et al. (2018) & $\begin{array}{l}\text { German } \\
\text { Jihadists }\end{array}$ & $\begin{array}{l}\text { Indications of } \\
\text { Mental } \\
\text { Illness }\end{array}$ & Prison Files & 16 & $31.3 \%$ \\
\hline LaFree et al. (2018) & U.S. Terrorists & $\begin{array}{l}\text { Indications of } \\
\text { Mental } \\
\text { Illness }\end{array}$ & Open Source & 284 & $43.7 \%$ \\
\hline Liem et al. (2018) & $\begin{array}{l}\text { Lone-Actor } \\
\text { Terrorists }\end{array}$ & $\begin{array}{l}\text { Indications of } \\
\text { Mental } \\
\text { Illness }\end{array}$ & Open-Source & 136 & $37.0 \%$ \\
\hline Zeman et al. (2018) & $\begin{array}{l}\text { Lone-Actor } \\
\text { Terrorists }\end{array}$ & $\begin{array}{l}\text { Confirmed } \\
\text { Diagnosis }\end{array}$ & Open-Source & 93 & $43.0 \%$ \\
\hline $\begin{array}{l}\text { Böckler et al. } \\
(2018)\end{array}$ & $\begin{array}{l}\text { German } \\
\text { Jihadists }\end{array}$ & $\begin{array}{l}\text { Confirmed } \\
\text { Diagnosis }\end{array}$ & $\begin{array}{l}\text { Closed \& } \\
\text { Open Source }\end{array}$ & 7 & $0.0 \%$ \\
\hline $\begin{array}{l}\text { Bubolz \& } \quad \text { Simi } \\
(2019)\end{array}$ & U.S. Far Right & $\begin{array}{l}\text { Indications of } \\
\text { Mental } \\
\text { Illness }\end{array}$ & Self-Report & 44 & $57.0 \%$ \\
\hline $\begin{array}{l}\text { Challacombe } \quad \& \\
\text { Lucas }(2019)\end{array}$ & $\begin{array}{l}\text { Violent } \\
\text { Sovereign } \\
\text { Citizens } \\
\end{array}$ & $\begin{array}{l}\text { Confirmed } \\
\text { Diagnosis }\end{array}$ & Police Files & 30 & $16.0 \%$ \\
\hline $\begin{array}{l}\text { Corner \& Gill, } \\
\text { 2019) }\end{array}$ & $\begin{array}{l}\text { Group Member } \\
\text { Terrorists }\end{array}$ & $\begin{array}{l}\text { Confirmed } \\
\text { Diagnosis }\end{array}$ & Self-Report & 97 & $11.9 \%$ \\
\hline Gill et al. (2019) & $\begin{array}{l}\text { Lone-Actor } \\
\text { Terrorists }\end{array}$ & $\begin{array}{l}\text { Confirmed } \\
\text { Diagnosis }\end{array}$ & Police Files & 49 & $32.7 \%$ \\
\hline Meloy et al. (2019) & U.S. Terrorists & $\begin{array}{l}\text { Confirmed } \\
\text { Diagnosis } \\
\end{array}$ & $\begin{array}{l}\text { Closed \& } \\
\text { Open Source }\end{array}$ & 31 & $48.4 \%$ \\
\hline Weenink (2019) & Dutch Jihadists & $\begin{array}{l}\text { Indications of } \\
\text { Mental } \\
\text { Illness }\end{array}$ & Police Files & 319 & $28.0 \%$ \\
\hline $\begin{array}{l}\text { Dhumad et al. } \\
(2020)\end{array}$ & Iraqi Jihadists & $\begin{array}{l}\text { Conduct } \\
\text { Disorder }\end{array}$ & $\begin{array}{l}\text { Clinical } \\
\text { Examination }\end{array}$ & 160 & $41.5 \%$ \\
\hline
\end{tabular}

Other mental health problems are also apparent within various studies. For example, Oppetit et al. (2019) examined the case files of 150 French individuals who sought to join ISIS. $12.7 \%$ 
spent time in psychiatric wards before their offense. Additionally, $29.3 \%$ had self-harmed prior to being radicalised. Several other studies similarly note suicidal ideation and/or suicide attempts (Bouzar and Martin, 2016; Ilardi, 2013; Corner \& Gill, 2019). In Simi et al's (2016) self-report study of 46 violent white supremacist groups members, the figure was as high as $57 \%$.

Collectively, these results largely dispel the myth there is no mental disorder presence within terrorist samples (see Corner \& Gill, 2017, for a discussion of this myth's origins). What we see is that mental health problems are relatively common within such studies, and are more easily identifiable when research teams are in proximity to the subjects, using standardised measures and/or have access to privileged closed-sources.

\section{Theme 2: Types and Rates of Mental Health Disorders}

Mental health disorders differ significantly from one another. Fewer studies provided detailed information on the types of disorders diagnosed within their samples. Some group-level studies note single instances of depression (Bakker, 2006), Asperger syndrome, schizophrenia (Knight et al., 2017), ADHD, psychotic disorder, borderline personality disorder and PTSS (Van Leyenhort and Andreas, 2017). Leygraf (2014) conducted court-ordered expert opinion on 29 individuals convicted of Jihadist-related crimes. Three individuals had schizophrenic psychosis whilst two had a primary dissocial problem. Weenink (2015) studied police files of 140 Dutch individuals who became foreign fighters. Disorders included psychotic, narcissistic, attentiondeficit/hyperactivity (ADD/HD), schizophrenia, autism spectrum, and post-traumatic stress (PTSD) disorders. In Corner, Gill, and Mason's (2016) sample of 153 lone-actor terrorists, $1.3 \%$ experienced traumatic brain injury, $0.7 \%$ drug dependence, $8.5 \%$ schizophrenia, $0.7 \%$ schizoaffective disorder, $2.0 \%$ delusional disorder, $0.7 \%$ psychotic disorder, $7.2 \%$ depression, $3.9 \%$ bipolar disorder, $1.3 \%$ unspecified anxiety disorder, $0.7 \%$ dissociative disorder, $1.3 \%$ obsessive compulsive disorder (OCD), 3.3\% PTSD, 0.7\% unspecified sleep disorder, 6.5\% unspecified personality disorder, and 3.3\% autism spectrum disorder. In Gill et al's (2019) closed source study of 49 UK lone-actor terrorists, $12.2 \%$ experienced a mood disorder, $10.2 \%$ schizophrenia, $4.1 \%$ intellectual disabilities, and $2 \%$ an assortment of personality disorders.

Collectively, the results clearly demonstrate there is no common diagnosis. Terrorist samples are marked by their diversity rather than their homogeneity. There are multiple pathways into violent extremism. Typically, multiple factors contribute to a single individual's pathway. These factors and their relative causal weight differ between individuals who become violent extremists. Individuals with very different initial states can experience different processes and still come to the same end outcome of violent extremism. In parallel research fields, this is known as the principle of equifinality (Borum, 2011).

\section{Theme 3: Comparison and Control Groups}

The majority of the previously cited studies solely focused upon violent extremist samples. Other study designs incorporated a comparative element. Typically, these come in one of three forms, which either compare (a) prevalence rates in violent extremist samples with general population rates, (b) those who do and do not hold violent extremist sympathies within the general population, and (c) different types of terrorists or compare with other violent offenders.

Three studies compared the prevalence rates of specific disorders with the general population base rate. Amongst Dutch foreign fighters, Weenink (2015) found elevated levels of schizophrenia and psychosis compared with the general population. In a greatly expanded dataset, Weenink (2019) additionally found elevated levels of psychotic disorders and PTSD. 
Amongst lone-actor terrorists, Corner et al. (2016) found elevated levels of schizophrenia, autism and delusional disorder.

Other studies make use of general population surveys to gauge the prevalence of, and predictors for, violent extremist beliefs. For example, Bhui et al. (2014) conducted a general population survey with a sample of 608 U.K. based Muslims. The authors collected data on individual sympathies for violent aggression alongside a number of other psychometric scales. The results demonstrated that those suffering from depression were significantly more likely to express such sympathies. In a follow-up study using the same data, Bhui et al. (2016) showed such individuals were almost twice as likely to express sympathy. Further follow up studies also highlighted correlations between anxiety and post-traumatic stress and sympathies for violent extremism (Bhui et al., 2019). Rousseau et al. (2019) replicated the results pertaining to depression in a Canadian context. They additionally found depression was a significant mediator of the effect of exposure to violence and discrimination and sympathies for violent radicalisation.

These results demonstrate factors associated with developing an attitudinal affinity with a cause (e.g. extremism) may not be associated with violence on behalf of that cause (e.g. violent extremism). Whilst studies by Rousseau and Bhui demonstrated a strong link between some facets of extremism and depression, Corner et al. (2016) found lower diagnosed rates of depression amongst lone-actor terrorists compared to the general population. So, whilst depression might contribute to extremist support more often than one would expect, it might also inhibit the violent expressions of this radicalisation in certain cases.

Four studies compared the rates of mental disorders in lone actors to matched samples of group actors. Gruenewald et al. (2013) compared far-right lone and group offenders, finding the former significantly more likely to have a reported history of mental illness (40.4\% vs. $7.6 \%$ ). Hewitt's (2003) sample of lone-actors from an array of ideological backgrounds found similar results $(22 \%$ vs. $8.1 \%)$ although the prevalence rate was almost half the rate in Gruenewald et al.'s study. Corner and Gill (2015) compared 119 lone-actor terrorists with 428 group-based actors. Lone-actor terrorists were 13.5 times more likely to have a history of mental illness than group-based actors. Corner, Gill and Mason (2015) examined these results further and documented a negative correlation between the level of co-offending and the rate of mental disorder prevalence. Whereas Corner and colleagues' sample of lone-actor terrorists included over $40 \%$ with a history of mental disorders, the figure for solo-terrorists (e.g. those who carried out their attack alone but received support from a wider terrorist group) was around $20 \%$; for dyads it was just over 5\% and for group-based actors it was less than 3\%. Lastly, it should be noted that two studies demonstrated lower rates of psychiatric illness (Lyons \& Harbinson, 1986) and conduct disorders (Dhumad et al., 2020) amongst violent extremists compared to non-ideologically inspired murderers.

Finally, Merari and colleagues carried out various psychological tests on a sample of suicide bombers and compared the results with various control groups (e.g. other terrorists and nonpolitical criminals) (Merari, 2009a, 2009b, 2010). These studies employed a range of techniques including clinical interviews, personality tests, the Thematic Apperception Test, and the House-Tree-Person Drawing test. Compared to the control group, the suicide bomber group received significantly more diagnoses of Avoidant-Dependent Personality Disorder (60\% vs. 17\%), depressive symptoms (53\% vs. $8 \%$ ) and more readily displayed suicidal tendencies $(40 \%$ vs. $0 \%)$. On the other hand, the control group was more likely to include members with psychopathic tendencies (25\% vs. $0 \%$ ) and impulsive-unstable tendencies (67\% 
vs. $27 \%$ ). Suicide bomber organizers scored higher in ego-strength, impulsivity and emotional instability than would-be suicide bombers.

Collectively, the results demonstrate the importance of carefully selecting control groups and outcome measures in the development of putative risk factors. Whilst some mental disorders (mood disorder and schizophrenia, for example) are found to be more prevalent in samples of violent extremists than in the general population, other types of psychiatric illness may manifest less frequently among violent extremists when compared to those who conduct similarly violent deeds absent an overarching political, social or religious cause.

\section{Theme 4: From Presence to Relevance}

Whilst the majority of aforementioned studies focus on the mere presence of mental health disorders in these groups, some aim to address the mechanisms and relevance of mental health disorders to individual cases. To do this, existing research has typically gone down the case study/vignette route. For example, Faccini and Allely (2017) outlined a series of short case studies demonstrating the functional links of autism and supporting or engaging in terrorism. They demonstrate how different autism-related deficits can contribute differently (e.g. increased social naivete, over-rigid adherence to rules, not understanding social situations, aggressiveness, obsessional interests). Similarly, Inderberg et al. (2019) offer three vignettes based on primary materials of the impact of autism and psychosis and how they engender a collapse of cognitive functioning and impulse control, and the ability to gauge the dangerousness/offensiveness of a situation. Post (2000) outlines his expert witness account of a trial in which the accused bomber had suffered from depression and PTSD prior to the offence and their functional roles. Ludot et al. (2016) report the cases of two teenagers undergoing psychological treatment and the relationship between their complex needs and radicalisation. Hemmingby and Bjorgo (2018) examine the impact of psychological make-up upon one terrorist attack using unique access to police and investigative files. Other in-depth case studies look at the impact of mental health crises upon the adoption of violent extremist views also (Gill, 2015; Holt et al, 2018; Erlandsson \& Meloy, 2018; Cotti \& Meloy, 2019).

Group level studies further demonstrate that mental health problems do not only increase individual vulnerabilities. They may, in certain circumstances, have other impacts. For example, sequence analyses of lone-actor terrorist data demonstrate that during radicalisation "mental health problems appear to be a precursor to, and consequence of, criminal behaviours, which are themselves markers of lack of commitment to prosocial moral rules (moral susceptibility) and/or markers of selection into criminogenic settings, some of which may be radicalising (including prison)" (Corner, Bouhana \& Gill, 2019: 120; see also Corner \& Gill, 2019). In other contexts, research shows how propaganda provided extremists with an explanation for their negative personal experiences including experiences of trauma and mental health problems. Mental health problems (or markers thereof), in certain circumstances, may also be attractive to particular recruiters for particular tasks and functions within an extremist network (Bubolz \& Simi, 2019).

Corner and Gill (2015) compared a sample of lone-actor terrorists with mental health disorders to a sample of lone-actor terrorists without them.. They former were just as (and in some cases more) likely to engage in a range of rational pre-attack behaviours as those who were not. Mentally disordered offenders were more likely to express violent desires, seek legitimization for their intended actions, stockpile weapons, train, carry out a successful attack, kill and injure, discriminate in their targeting, and claim responsibility. Most of these behaviors are typically viewed as rational and essential for success. The same study also showed that only being 
diagnosed with schizophrenia and associated disorders was significantly associated with previous violent behaviour, which supports past research.

\section{Theme 5: Complex Needs}

One takeaway from Table 2 is that it is only in the recent past where studies began to systematically collect data on mental health problems. However, there has been a longer tradition of collecting data on life experiences which other fields of research show have the potential for a detrimental impact upon mental health. As studies on lone-actor terrorists show, mental health disorders are likely to co-occur alongside a range of other stressors (Gill, 2015). Rather than an overt focus on mental health disorders, this section synthesises results focused upon wider complex needs. The National Health Service (NHS) defines a number of areas affecting our mental health: personal lives and relationships, discrimination, money/work/housing, life changes, health issues, traumatic events, and smoking/drinking/gambling/drug misuse. We look at the evidence for each within extremist samples in turn.

\section{Personal Lives and Relationships}

Various case studies utilising primary materials demonstrate the impact of bad relationships upon the radicalisation process (Jasko et al., 2017). This includes poor intimate partner relationships which have been linked with feelings of emptiness and isolation, search for security, commitment problems, and the development of new (extreme) relationships to replace the void (Aly \& Striegher, 2012; Bazex et al., 2017). Studies also examined the role of poor family relationships. For example, Bazex \& Mensat's (2016) interviews with 12 French jihadists showed the sample generally had negative relationships with their mothers, characterised by "insidious aggression" leading to a general ambivalence towards women in general. Half of Sieckelinck et al's (2017) (see also Sikkens et al., 2017, Sikkens, 2018) interview sample of former extremists $(n=21)$ depicted problematic family situations characterised as turbulent and instable. Finally, Rink and Sharma (2016) found troubled social relationships (parental relationships, respect from friends/family) significantly correlated with radicalization in their Kenyan survey. Other studies depict relatively high levels of bereavement (Bouzar \& Martin, 2016; Knight et al., 2017) and social isolation experienced prior to radicalisation (Böckler et al., 2015; Beardsley \& Beech, 2013; Botha et al, 2014, Knight et al, 2017).

\section{Discrimination}

Interview-based research designs vividly demonstrate the impact of perceived discrimination, victimisation and grievances upon radicalization processes and advocacy for violence against an out-group (Ali et al, 2017; Ferguson et al, 2008; Florez-Morris, 2007; Denov and Gervais, 2007; Glaser et al., 2002). Other research designs involving analysis of case files (Bouzar \& Martin, 2016), personal narratives (Schafer et al, 2014) and self-report surveys provide further validation (De Waele \& Pauwels, 2016; Costello et al, 2016; Victoroff, 2012). Doosje et al's (2013) structural equation modelling of survey data depicts factors like individual and collective deprivation being a root cause which inflates the likelihood of determinants of radical beliefs such as intergroup anxiety, perceptions of threat and perceived injustice as well as personal emotional uncertainty.

\section{Work and Unemployment}

Economic pressures are mentioned as a key driver into violent extremist scenes as diverse as U.S neo-Nazi's (Ezekiel, 1995, 2002; Baron, 1997) and al-Shabaab (Botha, 2014). Across 15 studies found in our initial search, unemployment rates averaged $19.79 \%$ ( $\mathrm{n}=2753$ participants) 
(Bakker, 2006; Baron, 1997; De Bie, 2016; Fair, 2008, Dean, 2007; Gill et al., 2017; Gill et al., 2014; Horgan \& Morrison, 2011; Horgan et al, 2016; Ducol, 2015; Jacques \& Taylor, 2013; Jasko et al., 2017; Meloy et al., 2015; Ozeren, 2014; Reynolds \& Hafez, 2019). In a comparative study of 77 U.K. jihadists and a representative sample of 1363 U.K. Muslims, Altunbas \& Thornton (2011) found the former significantly more likely unemployed despite having significantly more education (measured in years). In a general population survey, Bhui et al. (2016) found those unemployed were significantly more likely to express sympathies for violent extremism. In a comparison of violent and non-violent radicals, Bartlett and Miller (2012) found violent radicals more likely unemployed also. These issues obviously have other important impacts. Weenink (2019) found 9\% of his foreign fighter sample had been homeless for a period of time. This is approximately eight to ten times more likely than a matched general population sample. Similarly, Baron (1997) classified each of his 14 Canadian skinhead participants as chronically or long-term homeless.

\section{Life Changes}

Research commonly identifies a tipping point or a catalysing event that accelerated the movement from a violent belief system into violent behaviour. Sometimes these life changes encompass the loss of what had previously acted as a protective factor which buffered the other risk factors present in the individual's life. For example, Capellan's (2015) study of lone-actor terrorists found $45 \%$ had experienced a significant recent life change prior to their attack. Jasko et al. (2017) found $29 \%$ had experienced a loss of social standing and $36 \%$ had been kicked out or dismissed from social groups or organizations. Simi et al. (2013) demonstrate the impact of social stress resulting from major life and identity changes and its impact upon the hardening of a radicalised identity.

\section{Traumatic Experiences}

In terms of complex needs, the greatest variety, volume and quality of data exists on traumatic experiences prior to radicalisation (Post, 2000; Stern, 2014; Jasko et al., 2017; Klausen et al., 2016; Speckhard and Ahkmedova, 2006). For example, Bubolz and Simi (2019) provide a number of first-hand accounts of the relationship between early experiences of trauma, the development of mental health problems and the subsequent engagement with violent groups. Trauma comes in many forms and typically exceeds what is found in the general population (Simi et al, 2016). Studies have shown rates between:

- $\quad 17.6 \%$ and $71.4 \%$ who experienced physical abuse (Dhumad et al., 2020; Oppetit et al., 2019; Simi et al., 2016; Bazex et al.,2017; Baron, 1997; Jasko et al., 2017),

- $\quad 23 \%$ and 28.5\% sexual abuse (Oppetit et al., 2019; Simi et al., 2016; Baron, 1997),

- $\quad 16.35 \%$ and $85.3 \%$ neglect or psychological abuse (Oppetit et al., 2019; Dhumad et al., 2020; Simi et al., 2016; Bazex et al.,2017),

- $\quad 36 \%$ and $82 \%$ parental abandonment (Simi et al., 2016; Oppetit et al., 2019),

- $18.6 \%$ and 64\% domestic or neighbourhood violence (Oppetit et al., 2019; Simi et al, 2016; Bazex et al.,2017; Carmona Parra, 2012)

Baron (1997) argues such instances of abuse lead to distrust of authority figures, increased time on the streets with (delinquent) peers, increases the likelihood of violence being accepted as a method of dispute management, decreases empathy and makes the victimization of others more 
likely. Kleinmann (2012) adds negative self-esteem and identity issues as further knock-on effects of experienced trauma amongst violent extremists.

First-hand accounts demonstrate the influential role of traumatic experiences from statepolicies upon violent mobilization. Examples included forced relocation, state repression (Abbas \& Yigit, 2016), experience of violence by the other side (Ferguson et al., 2008), and state forces (Florez-Morris, 2007). Open source analysis of the backgrounds of over 200 Palestinian suicide bombers finds corroborating evidence (Gill, 2012).

\section{Substance Misuse and Addiction}

Case study designs (Aly \& Striegher, 2012) and group-level analyses assert a high degree of substance abuse. Closed source analyses demonstrate $22 \%$ of ISIS foreign fighters in France addicted to drugs (Oppetit, 2019) and 41.7\% of radicalised prisoners previously being regular drug users (Stys et al., 2014). 73\% of Simi et al's (2016) sample self-reported problems with alcohol and/or illegal drugs. Baron (1997) demonstrates 5 of his sample of 14 Canadian skinheads drank alcohol daily, 9 smoked marijuana or hashish daily, and 8 took LSD at least twice a week. There was also regular use of speed and solvents. In the year prior to the interviews, 8 had taken cocaine, 6 amphetamines and 7 heroin.

Various research designs demonstrate the functional role of substance misuse in the radicalisation process. Baron (1997) identified substance abuse as both (a) a management strategy for their earlier traumatic experiences and (b) heavily intertwined with their violent offending and criminal engagement. Ilardi's (2013:717) interviews with radicalised Muslims in Canada notes regular problems with drug, alcohol and gambling addictions prior to converting to Islam. "For these men, Islam was seen... as the means by which they could inject meaning into their wayward lives, providing a second chance at life during a time when they were most desperate and despondent". In other words, the turn to Islam was a response to their life problems. Finally, Denov and Gervais' (2007) depict drug misuse as a by-product of violent extremism, in this case group members used drugs to overcome the stress associated with conducting violence.

\section{Discussion}

The literature on mental health problems and violent extremism has gone through many stages (Gill \& Corner, 2017). From a position in the 1970s and 1980s that all terrorists, by definition, were psychopaths and narcissists, to the late 1990s and early 2000s which rightfully questioned the preceding evidence base. In the past decade, empiricism flourished. Studies differing in data sources, scientific methods and risk specifications consistently point toward the presence of mental health disorders in a minority of subjects. Studies also highlight the range and volume of co-occurring life stressors and complex needs. It is insufficient for us to solely focus upon single risk factors. The focus should rather be on the totality of an individual's circumstances.

Our more thorough and updated research synthesis broadly agrees with Misiak et al's (2019) point that a "unique profile of psychopathology or personality traits that makes individuals more prone to radicalization cannot be proposed based on available evidence." We similarly agree that lone- and group-terrorists may appear to be two distinct groups of people in terms of their drivers and criminogenic needs. However, we would go one step further and argue the evidence suggests this is also likely true for criminality writ-large and not just something specific to violent extremism (Gill, 2015). Our results should be seen as complementary and an elaboration on Misiak's review rather than a competing paper. With that in mind, we depart 
from their review's discussion by talking about the implications of our results for how we conceptualise violent extremism and the potential avenues for future research.

Research on violent extremism now largely agrees on two broad principles (Borum, 2011), both of which should be reflected in how we think about the relationships, plural intended, between violent extremism and mental health disorders. First, multiple pathways into violent extremism exist. Typically, multiple factors contribute to a single individual's pathway. These factors and their relative causal weight differ between individuals who become violent extremists. Individuals with very different initial states can experience different processes and still end at the same end outcome of violent extremism. In parallel research fields, this is known as the principle of equifinality. Second, different people with similar initial states may produce different outcomes. Additionally, the impact of experiencing a single factor may impact upon an individual's development in very different ways. In parallel research fields, this is known as the principle of multifinality (Borum, 2011). Both principles have an impact upon how we think about mental health problems, complex needs and violent extremism.

For equifinality, the results cited above demonstrate that no single terrorist profile exists. Most of the stressors outlined did not occur for more than $50 \%$ of any given sample. Although many studies showed elevated levels of mental health disorders in certain categories of terrorists (e.g. lone offenders vs. group offenders), the rates of mental disorders in these lone-actor samples never exceeded $45 \%$. The disorders also differed greatly. Even in those samples where diagnosed disorders were at the higher end of the spectrum, these individuals were also significantly more likely to experience other recent stressors than their non-mentally disordered counterparts (Corner \& Gill, 2015).

Rarely are mental health problems the sole issue. Sometimes mental health problems may compound other problems. Sometimes other problems may compound the mental health problems. It is the patterning of risk and protective factors we need to understand from case to case. The patterns will differ wildly. This has been demonstrated empirically. Clemmow et al. (2020a) disaggregated four patterns of interactions among risk factors and indicators in trajectories to lone-actor terrorist violence $(n=125)$. The offence process was theorised as dynamic interactions among individual-level susceptibilities (of which mental illness and psychological distress were two), situational factors, and exposure (operationalised as network connectivity). Four patterns, termed person-exposure patterns (PEPs), were identified; the solitary, susceptible, situational, and selection PEP. The solitary PEP lacked common indicators associated with a propensity for terrorist violence. The susceptible PEP was characterised by a cognitive susceptibly, manifesting as mental illness, as key to the emergence of the motivation to commit terrorist violence. The situational PEP demonstrated how situational stressors can signal acceleration towards an attack. Lastly, the selection PEP demonstrated a pattern of antecedent warning behaviours alongside an existing propensity for violence; thus demonstrating the equifinality of engaging in (here specifically lone-actor) terrorist violence.

Violent extremists may display similar risky and adverse behaviours, yet emerge from multiple pathways, some of which may involve mental health problems. Treating them as a homogeneous group because of their presenting behaviours (e.g. reading extremist propaganda) and instituting a single intervention (e.g. counter-narrative work) is insufficient. People may engage in such behaviours because of curiosity, peer-pressure, identity-seeking, fixation, social isolation, and other factors related or unrelated to mental health problems. Preventing individuals with mental health problems from becoming radicalised or going on to 
engage in violent extremism may necessitate tailored, rather than broad, generalised policies. If multiple trajectories into violent extremism exist, there should be multiple policies to encourage prevention. Not all policies will have relevance to all individuals presenting with the same mental health problems, as their constellation of other risk and protective factors likely differs.

For multifinality, even for those who become violently radicalised and who also suffer mental health problems, the role the latter plays differs from case to case. Where present, it might be a driving force, it might inflame other stressors and have a snowball effect, it might be a byproduct of violent extremism behaviours, or it might be playing no role whatsoever. We know from the general violence literature that this is also true for a single disorder (Howlin, 2004). We also know the factors associated with developing an attitudinal affinity with a cause (e.g. radicalisation) may not associate with violence on behalf of that cause (e.g. violent radicalisation).

Additionally, the same risk factors may be highly associated with multiple end outcomes. For example, in a survey of over 400 Hezbollah fighters, Schbley (2005:115-116) found a strong relationship between "some self-reported criteria of intermittent explosive, psychotic, and oppositional personality disorders and a person's absolutist tendency, affinity for martyrdom, susceptibility to the culting process, psychotic depression, and acts of terrorism and selfimmolation." Findings such as these highlight the role of services like PREVENT. It is true that very few of those on PREVENT's radar will go on to be Terrorism Act offenders and therefore be 'true positives.' However, if many of the cases experience the types of complex needs we have outlined, then they might likely be someone's 'true positive' at some point in the future if these needs are not addressed. The high degree of convergence between the risk factors included in general violence and extremist violence risk assessment instruments might be emblematic of this issue.

\section{Conclusion}

From a position of almost completely no data a decade ago, a range of studies highlight a minority presence of mental health disorders and a larger range and volume of other cooccurring complex needs. Although greater steps need to be taken to use standardised psychological tests, and definitions, the early results suggest it is a worthwhile pursuit. The aggregated prevalence rates also suggest that mental health disorders and other complex needs require consideration in risk assessment and management instruments.

There are a number of areas where future research should be oriented. As demonstrated throughout this review, the vast majority of empirical research on mental disorders and violent extremism takes the nomothetic route. Typically, the prevalence of mental health disorders is determined within large(ish) samples of terrorists and those with attitudinal affinity with a terrorist cause. Such approaches provide various 'counts' and enable within-group and acrossgroup comparisons. That is, the strategy gives a sense of how present mental health disorders are. In some cases, the analyses identify common relationships between variables. These insights, however, are to a large degree difficult to apply to a single case which needs assessing and managing in the here and now. In addition to understanding its 'presence', the 'relevance of mental health disorders for violent extremism must be determined. Doing so requires the identification of the mechanisms through which mental health problem impact upon violent extremism, and why the risk factor does not impact each individual equally. To this end, much more work that applies the idiographic perspective is needed. This could help untangle the 
relevance of mental health disorders in particular individuals who became violent extremists at particular moments in their life. As theme four demonstrates, in-depth accounts drawing upon primary and/or sensitive materials are few and far between. This, in turn, means we have comparatively little information on the 'relevance' of mental health problems compared to a much greater number of studies that simply described their 'presence.'

One simple route to developing a greater understanding the salience of different factors is by comparing their presence in a violent extremist population to a general population. The study of the prevalence rates of risk factors within non-offending populations is very minimal but methodological and empirical advancements have recently been made (Clemmow et al, 2020b).

Our results also orient readers to consider data provenance as the type of data appears to impact upon the prevalence rates found within a given study. The same is also true for how studies define mental health problems. A heretofore unmentioned caveat to consider is the variance in mental health help seeking and service provision across and within different national landscapes. Depending on the study, this may have large selection effects and potentially bias the results.

Although we touched upon definitional issues in theme one, the point also stands that much research in this area relies upon diagnostic and categorical approaches like the ICD and DSM. Such approaches have several problems. Resultingly, competing frameworks such as the Research Domain Criteria came to the fore (Cuthbert \& Insel, 2013). Such approaches understand mental disorders and traits to fall on continuums along multiple systems (e.g. negative valence, positive valence, cognition, social processing, arousal/modulatory). Whilst large steps have been made by this approach, not even its basic conceptual underpinning (let alone its precise specification) has yet to devolve into violent extremism studies. Embracing the Research Domain Criteria approach will open up new avenues for standardisable data collection, with increased units of analysis, to more fields of expertise (e.g. neuropsychology).

To date, the study of risk factors for violent extremism typically takes the form of traditional inferential analyses such as regression modelling. The recent increased use of structural equation modelling in survey-based designs have helped tease out the main, mediating and moderating impacts of various features upon violent extremist beliefs and intentions. Replications across different contexts are now necessary to tease out their generalisability. Further advances such as the adoption of network approach will also add novel insights. These approaches are increasingly popular in the psychological sciences, specifically in psychopathology, and emerged as an alternative to the latent variable model. Rather than conceptualising mental disorders, such as depression, as the root cause of passive symptoms, disorders are considered systems of mutually reinforcing interactions among symptoms (Borsboom, 2008). For instance, fatigue and low mood (symptoms of depression) in the latent variable model, are considered passive indicators of the underlying cause, depression. The alternative model states that fatigue and low mood interact with and cause each other. We argue that extremist risk can be conceptualised in the same way; where there is no underlying root cause, but rather risk emerges as the outcome of mutually reinforcing causal interactions. There are multiple datasets held within individual research teams that would be ideal for such modelling. Greater inter-disciplinary working underpinned by open science principles might expedite the answer to the question of what roles, if any, mental health problems might play in the adoption of violent extremist attitudes and in the enactment of violent extremism (Schumann, 2019). 


\section{References}

Abbas, T., \& Yigit, I. H. (2016). Perspectives on ethno-national conflict among Kurdish families with members in the PKK. Terrorism and Political Violence, 28(2), 297-315.

Ali, R. B. M., Moss, S. A., Barrelle, K., \& Lentini, P. (2017). Does the pursuit of meaning explain the initiation, escalation, and disengagement of violent extremists?. Aggression and violent behavior, 34, 185-192.

Altunbas, Y., \& Thornton, J. (2011). Are homegrown Islamic terrorists different? Some UK evidence. Southern Economic Journal, 78(2), 262-272.

Aly, A., \& Striegher, J. L. (2012). Examining the role of religion in radicalization to violent Islamist extremism. Studies in Conflict \& Terrorism, 35(12), 849-862.

Augestad Knudsen, R. (2020). Measuring radicalisation: risk assessment conceptualisations and practice in England and Wales. Behavioral Sciences of Terrorism and Political Aggression, 12(1), 37-54.

Bakker, E. (2006). Jihadi terrorists in Europe: Their characteristics and the circumstances in which they joined the jihad: An exploratory study. Netherlands Institute of International Relations Clingendael.

Baron, S. W. (1997). Canadian male street skinheads: street gang or street terrorists?. Canadian Review of Sociology/Revue canadienne de sociologie, 34(2), 125-154.

Bartlett, J., \& Miller, C. (2012). The edge of violence: Towards telling the difference between violent and non-violent radicalization. Terrorism and Political Violence, 24(1), 1-21.

Bazex, H., \& Mensat, J. Y. (2016, May). Who are the French jihadists? Analysis of 12 cases to help develop profiles and assessment of the risk of acting out. In Annales MedicoPsychologiques (Vol. 174, No. 4, pp. 257-265). 21 STREET CAMILLE DESMOULINS, ISSY, 92789 MOULINEAUX CEDEX 9, FRANCE: MASSON EDITEUR.

Bazex, H., Benezech, M., \& Mensat, J. Y. (2017, March). " The mirror of hatred". Prison treatment of radicalization: Clinical and criminological analysis of 112 persons under court. In ANNALES MEDICO-PSYCHOLOGIQUES (Vol. 175, No. 3, pp. 276-282). 21 STREET CAMILLE DESMOULINS, ISSY, 92789 MOULINEAUX CEDEX 9, FRANCE: MASSON EDITEUR.

Beardsley, N. L., \& Beech, A. R. (2013). Applying the violent extremist risk assessment (VERA) to a sample of terrorist case studies. Journal of Aggression, Conflict and Peace Research, 5(1), 4-15.

Bhui, K., \& Jones, E. (2017). The challenge of radicalisation: a public health approach to understanding and intervention. Psychoanalytic Psychotherapy, 31(4), 401-410.

Bhui, K., Everitt, B., \& Jones, E. (2014). Might depression, psychosocial adversity, and limited social assets explain vulnerability to and resistance against violent radicalisation?. PloS one, 9(9), e105918.

Bhui, K., Otis, M., Silva, M. J., Halvorsrud, K., Freestone, M., \& Jones, E. (2019). Extremism and common mental illness: cross-sectional community survey of White British and Pakistani men and women living in England. The British Journal of Psychiatry, 1-8.

Bhui, K., Silva, M. J., Topciu, R. A., \& Jones, E. (2016). Pathways to sympathies for violent protest and terrorism. The British Journal of Psychiatry, 209(6), 483-490.

Böckler, N., Leuschner, V., Zick, A., \& Scheithauer, H. (2018). Same but different? Developmental pathways to demonstrative targeted attacks-Qualitative case analyses of adolescent and young adult perpetrators of targeted school attacks and 
jihadi terrorist attacks in Germany. International journal of developmental science, 12(1-2), 5-24.

Borum, R. (2011). Radicalization into violent extremism II: A review of conceptual models and empirical research. Journal of strategic security, 4(4), 37-62.

Botha, A. (2014). Political socialization and terrorist radicalization among individuals who joined al-Shabaab in Kenya. Studies in Conflict \& Terrorism, 37(11), 895-919.

Bouhana, N., \& Wikstrom, P. O. (2011). Al Qai'da-Influenced Radicalisation: A Rapid Evidence Assessment Guided by Situational Action Theory.

Bouzar, D., \& Martin, M. (2016). What motives bring youth to engage in the Jihad. Neuropsychiatrie de l'Enfant et de l'Adolescent, 64(6), 353-59.

Bubolz, B. F., \& Simi, P. (2019). The Problem of Overgeneralization: The Case of Mental Health Problems and US Violent White Supremacists. American Behavioral Scientist, 0002764219831746.

Capellan, J. A. (2015). Lone wolf terrorist or deranged shooter? A study of ideological active shooter events in the United States, 1970-2014. Studies in Conflict \& Terrorism, 38(6), 395-413.

Capellan, J. A., \& Anisin, A. (2018). A Distinction Without a Difference? Examining the Causal Pathways Behind Ideologically Motivated Mass Public Shootings. Homicide Studies, 1088767918770704.

Carmona Parra, J. A., Moreno Martín, F., \& Tobón Hoyos, J. F. (2012). Child soldiers in Colombia: Five views. Universitas Psychologica, 11(3), 755-768.

Challacombe, D. J., \& Lucas, P. A. (2019). Postdicting violence with sovereign citizen actors: An exploratory test of the TRAP-18. Journal of Threat Assessment and Management, 6(1), 51.

Chermak, S., \& Gruenewald, J. A. (2015). Laying a foundation for the criminological examination of right-wing, left-wing, and Al Qaeda-inspired extremism in the United States. Terrorism and Political Violence, 27(1), 133-159.

Clemmow, C., Bouhana, N., \& Gill, P. (2020a). Analyzing person-exposure patterns in loneactor terrorism: Implications for threat assessment and intelligence gathering. Criminology \& Public Policy, 19(2), 451-482.

Clemmow, C., Schumann, S., Salman, N. L., \& Gill, P. (2020b). The base rate study: developing base rates for risk factors and indicators for engagement in violent extremism. Journal of forensic sciences, 65(3), 865-881.

Corner, E., \& Gill, P. (2015). A false dichotomy? Mental illness and lone-actor terrorism. Law and Human Behavior, 39(1), 23.

Corner, E., \& Gill, P. (2019). Psychological Distress, Terrorist Involvement and Disengagement from Terrorism: A Sequence Analysis Approach. Journal of Quantitative Criminology, 1-28.

Corner, E., Bouhana, N., \& Gill, P. (2019). The multifinality of vulnerability indicators in lone-actor terrorism. Psychology, Crime \& Law, 25(2), 111-132.

Corner, E., Gill, P., \& Mason, O. (2016). Mental health disorders and the terrorist: A research note probing selection effects and disorder prevalence. Studies in Conflict \& Terrorism, 39(6), 560-568.

Costello, M., Hawdon, J., Ratliff, T., \& Grantham, T. (2016). Who views online extremism? Individual attributes leading to exposure. Computers in Human Behavior, 63, 311320.

Cotti, P., \& Meloy, J. R. (2019). The Tamerlan Tsarnaev case: The nexus of psychopathology and ideology in a lone actor terrorist. Journal of Threat Assessment and Management.

Cotti, P., \& Meloy, J. R. (2019). The Tamerlan Tsarnaev case: The nexus of psychopathology and ideology in a lone actor terrorist. Journal of Threat Assessment and Management. 
Cuthbert, B. N., \& Insel, T. R. (2013). Toward the future of psychiatric diagnosis: the seven pillars of RDoC. BMC medicine, 11(1), 126.

De Bie, J. L., \& De Poot, C. J. (2016). Studying police files with grounded theory methods to understand Jihadist networks. Studies in Conflict \& Terrorism, 39(7-8), 580-601.

De Waele, M., \& Pauwels, L. J. R. (2016). Why do Flemish youth participate in right- wing disruptive groups? In C. Maxson \& F. Esbensen (Eds.), Gang transitions and transformations in an international context (pp. 173-200). New York, NY: Springer.

De Waele, M., \& Pauwels, L. J. R. (2016). Why do Flemish youth participate in right- wing disruptive groups? In C. Maxson \& F. Esbensen (Eds.), Gang transitions and transformations in an international context (pp. 173-200). New York, NY: Springer.

Dean, G. (2007). Criminal profiling in a terrorism context. In Criminal profiling (pp. 169188). Humana Press.

Denov, M., \& Gervais, C. (2007). Negotiating (in) security: agency, resistance, and resourcefulness among girls formerly associated with Sierra Leone's Revolutionary United Front. Signs: Journal of Women in Culture and Society, 32(4), 885-910.

Dhumad, S., Candilis, P. J., Cleary, S. D., Dyer, A. R., \& Khalifa, N. (2020). Risk factors for terrorism: a comparison of family, childhood, and personality risk factors among Iraqi terrorists, murderers, and controls. Behavioral sciences of terrorism and political aggression, 12(1), 72-88.

Dom, G., Schouler-Ocak, M., Bhui, K., Demunter, H., Kuey, L., Raballo, A., ... \& Samochowiec, J. (2018). Mass violence, radicalization and terrorism: A role for psychiatric profession?. European psychiatry, 49, 78-80.

Doosje, B., Loseman, A., \& Van Den Bos, K. (2013). Determinants of radicalization of Islamic youth in the Netherlands: Personal uncertainty, perceived injustice, and perceived group threat. Journal of Social Issues, 69(3), 586-604.

Ducol, B. (2015). Devenir jihadiste à l'ère numérique: une approche processuelle et situationnelle de l'engagement jihadiste au regard du Web.

Ellis, B. H., \& Abdi, S. (2017). Building community resilience to violent extremism through genuine partnerships. American Psychologist, 72(3), 289.

Erlandsson, A., \& Reid Meloy, J. (2018). The Swedish school attack in Trollhättan. Journal of forensic sciences, 63(6), 1917-1927.

Ezekiel, R. S. (1995). The racist mind: Portraits of American neo-Nazis and Klansmen. New York.

Ezekiel, R. S. (2002). An ethnographer looks at Neo-Nazi and Klan groups: The racist mind revisited. American Behavioral Scientist, 46(1), 51-71.

Faccini, L., \& Allely, C. S. (2017). Rare instances of individuals with autism supporting or engaging in terrorism. Journal of Intellectual Disabilities and Offending Behaviour.

Fair, C. C. (2008). The educated militants of Pakistan: implications for Pakistan's domestic security. Contemporary South Asia, 16(1), 93-106.

Ferguson, N., Burgess, M., \& Hollywood, I. (2008). Crossing the Rubicon: Deciding to become a paramilitary in Northern Ireland. International Journal of Conflict and Violence (IJCV), 2(1), 130-137.

Florez-Morris, M. (2007). Joining guerrilla groups in Colombia: Individual motivations and processes for entering a violent organization. Studies in Conflict \& Terrorism, 30(7), 615-634.

Gill, P. (2020). The Data Collection Challenge: Experiences Studying Lone-actor Terrorism. Washington, D.C.: RESOLVE Network, 2020. https://doi.org/10.37805/rve2020.2

Gill, P., \& Corner, E. (2017). There and back again: The study of mental disorder and terrorist involvement. American Psychologist, 72(3), 231. 
Gill, P., Corner, E., Conway, M., Thornton, A., Bloom, M., \& Horgan, J. (2017). Terrorist use of the Internet by the numbers: Quantifying behaviors, patterns, and processes. Criminology \& Public Policy, 16(1), 99-117.

Gill, P., Corner, E., McKee, A., Hitchen, P., \& Betley, P. (2019). What do closed source data tell us about lone actor terrorist behavior? A research note. Terrorism and Political Violence, 1-18.

Gill, P., Horgan, J., \& Deckert, P. (2014). Bombing alone: Tracing the motivations and antecedent behaviors of lone-actor terrorists. Journal of forensic sciences, 59(2), 425435.

Glaser, J., Dixit, J., \& Green, D. P. (2002). Studying hate crime with the internet: What makes racists advocate racial violence?. Journal of Social Issues, 58(1), 177-193.

Gruenewald, J., Chermak, S., \& Freilich, J. D. (2013). Distinguishing "loner" attacks from other domestic extremist violence: A comparison of far-right homicide incident and offender characteristics. Criminology \& Public Policy, 12(1), 65-91.

Hemmingby, C., \& Bjørgo, T. (2018). Terrorist Target Selection: The Case of Anders Behring Breivik. Perspectives on Terrorism, 12(6), 164-176.

Hewitt, C. (2003). Understanding terrorism in America: From the Klan to al Qaeda. Psychology Press.

Holt, T. J., Freilich, J. D., Chermak, S. M., \& LaFree, G. (2018). Examining the utility of social control and social learning in the radicalization of violent and non-violent extremists. Dynamics of Asymmetric Conflict, 11(3), 125-148.

Horgan, J. (2005). The psychology of terrorism. Routledge.

Horgan, J., \& Morrison, J. F. (2011). Here to stay? The rising threat of violent dissident Republicanism in Northern Ireland. Terrorism and Political Violence, 23(4), 642-669.

Horgan, J., Shortland, N., Abbasciano, S., \& Walsh, S. (2016). Actions speak louder than words: A behavioral analysis of 183 individuals convicted for terrorist offenses in the United States from 1995 to 2012. Journal of forensic sciences, 61(5), 1228-1237.

Hurlow, J., Wilson, S., \& James, D. V. (2016). Protesting loudly about Prevent is popular but is it informed and sensible?. BJPsych bulletin, 40(3), 162-163.

Ilardi, G. J. (2013). Interviews with Canadian radicals. Studies in Conflict \& Terrorism, 36(9), 713-738.

Inderberg, A. M. S., Horndalsveen, K., Elvehaug, A. H., Mehmi, Y., Jørstad, I., \& Bakken, T. L. (2019). Autism, intellectual disabilities and additional psychosis, and affiliation to groups with violent ideology. Journal of Intellectual Disabilities and Offending Behaviour.

Jacques, K., \& Taylor, P. J. (2013). Myths and realities of female-perpetrated terrorism. Law and human behavior, 37(1), 35 .

James, D. V., \& Hurlow, J. (2016). A 21st century truism. BJPsych bulletin, 40(6), 346-346.

Jasko, K., LaFree, G., \& Kruglanski, A. (2017). Quest for significance and violent extremism: The case of domestic radicalization. Political Psychology, 38(5), 815-831.

Khoshnood, A. (2017). The correlation between mental disorders and terrorism is weak. BJPsych Bull, 4l(1), 56.

King, S., Endres, J., Schwaß, M., Stemmler, M., Lauchs, L., \& Armborst, A. (2018). Prisoners with islamist relations: are prisoner files a valuable data source for individual assessment and for research?. International journal of developmental science, 12(1-2), 129-141.

Klausen, J., Campion, S., Needle, N., Nguyen, G., \& Libretti, R. (2016). Toward a behavioral model of "homegrown" radicalization trajectories. Studies in Conflict \& Terrorism, 39(1), 67-83. 
Kleinmann, S. M. (2012). Radicalization of homegrown Sunni militants in the United States: Comparing converts and non-converts. Studies in Conflict \& Terrorism, 35(4), 278297.

Knight, S., Woodward, K., \& Lancaster, G. L. (2017). Violent versus nonviolent actors: An empirical study of different types of extremism. Journal of Threat Assessment and Management, 4(4), 230.

Koehler, D. (2015). Family counselling, de-radicalization and counter-terrorism: the Danish and German programs in context. Countering violent extremism: developing an evidence-base for policy and practice, 129-138.

LaFree, G., Jensen, M. A., James, P. A., \& Safer-Lichtenstein, A. (2018). Correlates of violent political extremism in the United States. Criminology, 56(2), 233-268.

Lankford, A. (2013). A comparative analysis of suicide terrorists and rampage, workplace, and school shooters in the United States from 1990 to 2010. Homicide studies, 17(3), 255-274.

Leygraf, N. (2014). Zur Phänomenologie islamistisch-terroristischer Straftäter. Forensische Psychiatrie, Psychologie, Kriminologie, 8(4), 237-245.

Liem, M., van Buuren, J., de Roy van Zuijdewijn, J., Schönberger, H., \& Bakker, E. (2018). European lone actor terrorists versus "common" homicide offenders: An empirical analysis. Homicide studies, 22(1), 45-69.

Ludot, M., Radjack, R., \& Moro, M. R. (2016). «Radicalisation djihadiste» et psychiatrie de l'adolescent. Neuropsychiatrie de l'Enfance et de l'Adolescence, 64(8), 522-528.

Lyons, H. A., \& Harbinson, H. J. (1986). A comparison of political and non-political murderers in Northern Ireland, 1974-84. Medicine, Science and the Law, 26(3), 193198.

McCurrie, T. (1998). White racist extremist gang members: A behavioral profile. Journal of Gang Research, 5(2), 51-60.

McGarry, P. J. (2016). Terrorism: it's not mental illness-it's politics. BJPsych bulletin, 40(5), 285-285.

Meloy, J. R., Goodwill, A. M., Meloy, M. J., Amat, G., Martinez, M., \& Morgan, M. (2019). Some TRAP-18 indicators discriminate between terrorist attackers and other subjects of national security concern. Journal of Threat Assessment and Management.

Meloy, J. R., Roshdi, K., Glaz-Ocik, J., \& Hoffmann, J. (2015). Investigating the individual terrorist in Europe. Journal of Threat Assessment and Management, 2(3-4), 140.

Merari, A. (2010). Driven to death: Psychological and social aspects of suicide terrorism. Oxford University Press.

Merari, A., Diamant, I., Bibi, A., Broshi, Y., \& Zakin, G. (2009a). Personality characteristics of "self martyrs"/"suicide bombers" and organizers of suicide attacks. Terrorism and Political Violence, 22(1), 87-101.

Merari, A., Fighel, J., Ganor, B., Lavie, E., Tzoreff, Y., \& Livne, A. (2009b). Making Palestinian "martyrdom operations"/"suicide attacks": Interviews with would-be perpetrators and organizers. Terrorism and Political Violence, 22(1), 102-119.

Misiak, B., Samochowiec, J., Bhui, K., Schouler-Ocak, M., Demunter, H., Kuey, L., ... \& Dom, G. (2019). A systematic review on the relationship between mental health, radicalization and mass violence 2 . European Psychiatry, 56(1), 51-59.

Oppetit, A., Campelo, N., Bouzar, L., Pellerin, H., Hefez, S., ..., Cohen, D.,. (2019). Do radicalized minors have different social and psychological profiles from radicalized adults?. Frontiers in psychiatry, 10, 644.

Ostwaldt, J. (2018) Closing the "Critical Disconnect ". The establishment of regional prevention networks at the interface of prevention and deradicalisation work using the 
example of the Federal State Democracy Centre Baden-Wuerttemberg. Journal for Deradicalization, (14), 218-248.

Özeren, S., Sever, M., Yilmaz, K., \& Sözer, A. (2014). Whom do they recruit?: Profiling and recruitment in the PKK/KCK. Studies in conflict \& terrorism, 37(4), 322-347.

Pathé, M. T., Haworth, D. J., Goodwin, T. A., Holman, A. G., Amos, S. J., Winterbourne, P., \& Day, L. (2018). Establishing a joint agency response to the threat of lone-actor grievance-fuelled violence. The Journal of Forensic Psychiatry \& Psychology, 29(1), 37-52.

Perry, S., Hasisi, B., \& Perry, G. (2017). Who is the lone terrorist? A study of vehicle-borne attackers in Israel and the West Bank. Studies in Conflict \& Terrorism, 1-15.

Post, J. M. (2000). Terrorist on trial: The context of political crime. Journal of the American Academy of Psychiatry and the Law.

Reynolds, S. C., \& Hafez, M. M. (2019). Social network analysis of German foreign fighters in Syria and Iraq. Terrorism and Political Violence, 31(4), 661-686.

Rink, A., \& Sharma, K. (2018). The determinants of religious radicalization: Evidence from Kenya. Journal of Conflict Resolution, 62(6), 1229-1261.

Rousseau, C., Hassan, G., Miconi, D., Lecompte, V., Mekki-Berrada, A., El Hage, H., \& Oulhote, Y. (2019). From social adversity to sympathy for violent radicalization: the role of depression, religiosity and social support. Archives of public health, 77(1), 45.

Schafer, J. A., Mullins, C. W., \& Box, S. (2014). Awakenings: The emergence of white supremacist ideologies. Deviant Behavior, 35(3), 173-196.

Schbley, A., \& McCauley, C. (2005). Political, religious, and psychological characteristics of Muslim protest marchers in eight European cities: Jerusalem Day 2002. Terrorism and Political Violence, 17(4), 551-572.

Schuurman, B. (2018). Research on terrorism, 2007-2016: A review of data, methods, and authorship. Terrorism and Political Violence, 1-16.

Sieckelinck, S., Sikkens, E., Van San, M., Kotnis, S., \& De Winter, M. (2019). Transitional journeys into and out of extremism. A biographical approach. Studies in Conflict \& Terrorism, 42(7), 662-682.

Sikkens, E., Sieckelinck, S., van San, M., \& de Winter, M. (2017). Parental reaction towards radicalization in young people. Child \& Family Social Work, 22(2), 1044-1053.

Sikkens, E., van San, M. R. P. J. R. S., Sieckelinck, S. M. A., \& de Winter, M. (2017). Parental Influence on Radicalization and De-radicalization according to the Lived Experiences of Former Extremists and their Families. Journal for Deradicalization, 12, 192-226.

Silke, A. (2004). Research on terrorism. Trends, Achievements and Failures. London: Frank Cass.

Simi, P., Bubolz, B. F., \& Hardman, A. (2013). Military experience, identity discrepancies, and far right terrorism: An exploratory analysis. Studies in Conflict \& Terrorism, 36(8), 654-671.

Simi, P., Sporer, K., \& Bubolz, B. F. (2016). Narratives of childhood adversity and adolescent misconduct as precursors to violent extremism: A life-course criminological approach. Journal of research in crime and delinquency, 53(4), 536563.

Speckhard, A., \& Ahkmedova, K. (2006). The making of a martyr: Chechen suicide terrorism. Studies in conflict \& Terrorism, 29(5), 429-492.

Stern, J. E. (2014). X: A Case Study of a Swedish Neo-Nazi and His Reintegration into Swedish Society. Behavioral sciences \& the law, 32(3), 440-453. 
Stys, Y. et al. (2014) Radicalization, E. Violent Extremists in Federal Institutions: Estimating Radicalization and Susceptibility to Radicalization in the Federal Offender Population.

Summerfield, D. (2016). Protesting loudly about Prevent is popular but is it informed and sensible? Reply. PSYCHIATRIC BULLETIN, 40(3), 163-163.

van Leyenhorst, M., \& Andreas, A. (2017). Dutch Suspects of Terrorist Activity: A Study of Their Biographical Backgrounds Based on Primary Sources. Journal for Deradicalization, (12), 309-344.

Victoroff, J. (2005). The mind of the terrorist: A review and critique of psychological approaches. Journal of Conflict resolution, 49(1), 3-42.

Victoroff, J., Adelman, J. R., \& Matthews, M. (2012). Psychological factors associated with support for suicide bombing in the Muslim diaspora. Political Psychology, 33(6), 791-809.

Weenink, A. W. (2015). Behavioral problems and disorders among radicals in police files. Perspectives on terrorism, 9(2).

Weenink, A. W. (2019). Adversity, Criminality, and Mental Health Problems in Jihadis in Dutch Police Files. Perspectives on Terrorism, 13(5), 130-142.

Weine, S., \& Kansal, S. (2019). What should global mental health do about violent extremism?. Global Mental Health, 6.

Weine, S., Eisenman, D. P., Jackson, L. T., Kinsler, J., \& Polutnik, C. (2017). Utilizing mental health professionals to help prevent the next attacks. International review of psychiatry, 29(4), 334-340.

Younis, T., \& Jadhav, S. (2019). Islamophobia in the National Health Service: an ethnography of institutional racism in PREVENT's counter-radicalisation policy. Sociology of Health \& Illness.

Zeman, T., Břeň, J., \& Urban, R. (2018). PROFILE OF A LONE WOLF TERRORIST: A CRISIS MANAGEMENT PERSPECTIVE. Journal of Security \& Sustainability Issues, $8(1)$. 